\title{
Michał Snopek
}

\section{POLITYKA ENERGETYCZNA PAŃSTW AZJATYCKICH}

Joanna Marszałek-Kawa, Kazimierz Pająk (red.), Polityka energetyczna państw Azji i Pacyfiku w XXI wieku, Wydawnictwo Adam Marszałek, Toruń 2015, ss. 206.

Praca zbiorowa Polityka energetyczna państw Azji i Pacyfiku w XXI wieku powstała pod redakcją prof. Joanny Marszałek-Kawy oraz prof. Kazimierza Pająka. Prof. Marszałek-Kawa jest absolwentką prawa na Wydziale Prawa i Administracji Uniwersytetu Mikołaja Kopernika w Toruniu, drugi z redaktorów prof. Kazimierz Pająk z Wydziału Ekonomii Uniwersytetu Ekonomicznego w Poznaniu, jest przewodniczącym Rady Naukowej Stowarzyszenia Energii Odnawialnej PGE. Celem książki jest zaprezentowanie metod oraz zasad rządzących polityką energetyczną państw azjatyckich. Należy zauważyć, że w ostatnich latach problem związany z zapewnieniem bezpieczeństwa energetycznego oraz ogólnie z polityką energetyczną stał się jednym z najczęściej poruszanych w debacie politycznej i medialnej. Impuls do wzmocnienia roli tej dziedziny dały wydarzenia w Japonii z marca $2011 \mathrm{r}$. Wtedy to na sile przybrały kwestie związane z ekologią i poczuciem bezpieczeństwa. Wagę tej gałęzi polityki podniosły późniejsze wydarzenia na Krymie i polityka Federacji Rosyjskiej, ponadto następstwa arabskiej wiosny oraz wojny, która swoim zasięgiem objęła Syrię i Irak, a teraz rzutuje na bezpieczeństwo i stabilność całego regionu.

Autorzy książki wychodzą naprzeciw oczekiwaniom co do pogłębionych studiów w tej dziedzinie. Także zgodnie z duchem czasu odchodzą od zagadnienia ograniczania się do „dyplomacji rurociągów” bądź zapewnienia bezpieczeństwa energetycznego w rozumieniu dostępności do surowców energetycznych po ak- 
ceptowalnej przez państwo cenie ${ }^{1}$. Zwracają za to uwagę na kwestie ekologiczne zarówno w wymiarze lokalnym, jak i międzynarodowym. Podejmowane tematy są zatem aktualne oraz istotne zarówno dla elit politycznych, gospodarczych, jak i dla przeciętnych obywateli.

Praca składa się z dziesięciu tekstów, przy czym należy tu zwrócić uwagę na ich kolejność. Wydawałoby się, że najlepszą metodą prezentacji materiałów byłoby przedstawienie zagadnień ogólnych, dotyczących całego regionu, a następnie wybranych państw w porządku geograficznym, znaczenia politycznego, siły oddziaływania gospodarki bądź innych. Książka zaczyna się zgodnie z oczekiwaniami od ciekawego tekstu Marcina Leźnickiego i Aleksandry Lewandowskiej, którzy zaprezentowali sprawy związane z zagrożeniami ekologicznymi w wybranych państwach reprezentatywnych dla całości. Autorzy wykazali związki pomiędzy wzrostem gospodarczym państw azjatyckich a zmianami dokonanymi przez człowieka w środowisku przyrodniczym.

Następne teksty sprawiają wrażenie, jakby do ich grupowania wykorzystano klucz tematyczny. W takim wypadku blok pierwszy mógłby dotyczyć energetyki jądrowej, drugi tradycyjnej energetyki opartej na ropie, a trzeci odnawialnych źródeł energii. Jeśli takie było zamierzenie redaktorów naukowych, to pomysł ten nie do końca został zrealizowany. Przechodząc od kolejnych tekstów do następnych, ma się czasami wrażenie przypadkowości, jak w przypadku prac Pawła Wiszniuka Przed i po Fukushimie. Wcześniejsze wypadki i możliwości odrodzenia sie japońskiego przemystu nuklearnego, Aleksandry Kozioł Polityka energetyczna Federacji Rosyjskiej w Azji za prezydentury Władimira Putina. Uwarunkowania, Tomasza Młynarskiego Strategiczne partnerstwo Francji i Chin w sektorze energetyki jąrowej czy prac Magdaleny Gołębiowskiej-Śmiałek Dyplomacja rurociagów: kompleks bezpieczeństwa energetycznego w Azji i Grzegorza Nizioła Powraca woda do Jeziora Aralskiego. W pierwszym wypadku pomiędzy dwoma tekstami dotyczącymi kwestii ściśle związanych z energetyką jądrową umieszczony został tekst dotyczący ogólnych zasad rządzących polityką energetyczną Federacji Rosyjskiej. W drugim przypadku praca Grzegorza Nizioła skupia się w znacznym stopniu na kwestiach ekologicznych i można by rozważyć przeniesienie tego tekstu na początek książki. Z drugiej strony, jest on także doskonałym wstępem do kolejnej części na temat odnawialnych źródeł energii. Ten dysonans, który pojawia się przy czytaniu, wskazuje, że pierwsze pięć opracowań można było rozłożyć w sposób bardziej przemyślany.

Problemy takie nie występują w ostatnim - trzecim bloku. W jego skład wchodzą wspomniana praca Nizioła, w której autor w sposób prosty i łatwy do zrozu-

1 Jacek Czaputowicz, Bezpieczeństwo międzynarodowe: współczesne koncepcje, Wydawnictwo Naukowe PWN, Warszawa 2012, s. 92. 
mienia przedstawia przyczyny wysychania Jeziora Aralskiego, wskazując równocześnie na wspólne oraz sprzeczne interesy państw regionu, a także omawia działania podjęte w celu odwrócenia katastrofy naturalnej. W kolejnym tekście zatytułowanym Woda - surowiec energetyczny dla państw Bliskiego Wschodu autorstwa Macieja Konrada Grzywacza i Zuzanny Melerskiej omówiona została rola gospodarki wodnej w relacjach pomiędzy państwami regionu, kwestie jej deficytu oraz wykorzystywania do produkcji żywności. Podobnie jak w poprzednim tekście również tu autorzy skupili się bardziej na problemach ekologicznych niż na polityce energetycznej. Trzecia praca autorstwa Agnieszki Drzymały Zastosowanie odnawialnych źródet energii w Japonii dotyczy nie tylko wewnątrzkrajowych uwarunkowań przyjęcia określonego modelu wytwarzania energii - autorka zwróciła również uwagę na aspekt międzynarodowy. Dzięki temu osoba dopiero zaznajamiająca się z tematem może prześledzić zobowiązania podjęte przez Japonię na arenie międzynarodowej, a następnie sposoby ich realizacji w polityce wewnętrznej. Daje to szansę lepszego zrozumienia tematu, niż gdyby ograniczono się tylko do kwestii wewnętrznych bądź międzynarodowych. Kolejne dwa teksty można uznać za całość, gdyż oba dotyczą ewolucji chińskiej drogi do gospodarki niskoemisyjnej. Zdecydowanie wyróżnia się tu druga praca pod tytułem Droga Chin do gospodarki niskoemisyjnej autorstwa Kazimierza Pająka, Joanny Mazurkiewicz oraz Piotra Lisa. Autorzy dobrze wyjaśniają kwestie ekonomiczne związane z przestawieniem się gospodarki na odnawialne źródła energii. Dzięki dobremu zestawieniu państw, w skład których weszły zarówno kraje starej Unii, jak i Europy Środkowo-Wschodniej, czytelnik może porównać etap, na którym znajdują się Chiny. Pierwszy tekst autorstwa Julii Kokocińskiej, zatytułowany Analiza i ocena czynników rozwoju inwestycji w odnawialne źródła energii w Chinach stanowi doskonałe wprowadzenie do następnej pracy, wnosi również dużo informacji o potencjale energii odnawialnej oraz działaniach podejmowanych przez rząd w celu jej promocji.

Biorąc pod uwagę pewne mankamenty, o których wspomniałem, należy uznać, że przyjęty model podziału pracy na bloki tematyczne zdał egzamin.

Wśród mocnych i słabych stron książki znaczna część wywodzi się z samego charakteru pracy. Gdyby pisał ją jeden autor, byłby on w stanie spójnie i wyczerpująco zaprezentować informacje oraz ich analizę. Każdy kolejny rozdział byłby powiązany z poprzednim i w jakiś sposób rozszerzałby wcześniej pozyskaną wiedzę. W przypadku prac zbiorowych ta ciągłość nie występuje, teksty stanowią mniej lub bardziej zamkniętą całość. Dlatego nie da się w nich w pełni zaprezentować tematu. Naturalnie należy więc przyjąć, że zamieszczone teksty albo są przyczynkami do bardziej szczegółowej analizy, albo analizą bardzo wąskiego wycinka tematu, który da się dość szczegółowo omówić na ograniczonej liczbie stron. 
Kolejna istotna wada związana jest z wiedzą oraz zainteresowaniami autorów. Poziom tekstów w ramach książki jest różny, mamy prace bardzo trafne (w ramach omawianej pozycji do takich należy zaliczyć Droge Chin do gospodarki niskoemisyjnej, Zastosowanie odnawialnych źródet energii w Japonii, Politykę energetyczna Federacji Rosyjskiej w Azji za prezydentury Władimira Putina), jak i słabsze (o nich będzie dalej). Dlatego nad wyraz istotną rolę w odpowiednim doborze uczestników projektu odgrywa tu redaktor naukowy.

Nie oznacza to oczywiście, że taka formuła ma tylko wady, bo zalety równoważą wspomniane mankamenty. Praca zbiorowa pozwala na zaprezentowanie tego, co często jest niemożliwe do omówienia w jednej książce ze względów ekonomicznych. Napisanie pozycji w pełni wyczerpującej dany temat, szczególnie w dziedzinie nauk społecznych, w których opisywany przedmiot ciągle się zmienia, może się stać opus vitae badacza. Praca zbiorowa, w której wielu badaczy porusza różne zagadnienia związane z tematem książki, pozwala na jego szersze ujęcie. Dzięki temu istnieje możliwość przedstawienia wielu aspektów i w ten sposób poszerzenia wiedzy czytelnika. Przy takim podejściu możliwe było zaprezentowanie analizy wielu państw z kontynentu azjatyckiego, a nie tylko jednego bądź wybranego regionu.

Także to, co wcześniej wskazałem jako wadę, to znaczy wielu autorów, zarazem również stanowi o mocnej stronie pracy. Każdy autor podchodzi do danego zagadnienia indywidualnie i wykorzystuje inne perspektywy teoretyczne, co sprawia, że nawet prace na ten sam temat w jednym zbiorze mogą przedstawiać problem z innej strony. W omawianej pozycji możemy wyróżnić dwa takie przypadki. Pierwszy z nich dotyczy tekstów Przed i po Fukushimie. Wcześniejsze wypadki i możliwości odrodzenia sięjapońskiego przemystu nuklearnego oraz Zastosowanie odnawialnych źródet energii w Japonii. Obie prace dotyczą energetyki jądrowej. Pierwsza z nich skupia się bardziej na zagrożeniach z niej płynących oraz na nieodpowiednim zarządzaniu ze strony japońskiej. Druga ma charakter bardziej neutralny i prezentuje energetykę jądrową jako jedną $\mathrm{z}$ alternatyw gospodarki opartej na węglu i ropie.

Kolejne dwie prace, które również częściowo poruszają ten sam temat, to Analiza i ocena czynników rozwoju inwestycji $w$ odnawialne źródła energii $w$ Chinach oraz Droga Chin do gospodarki niskoemisyjnej. Zależności te już omówiłem.

$\mathrm{Na}$ koniec chciałbym zasygnalizować indywidualne błędy w poszczególnych opracowaniach. Pierwszy dotyczy tekstu Eko-polityka wobec środowiskowych zagrożeń cywilizacyjnych (na wybranych przykładach państw azjatyckich). Zarzut dotyczy niewystarczającej argumentacji co do wybranych państw. Autorzy opisali zasady ekopolityki na przykładzie Chin, Japonii, Indii, Korei Południowej oraz Indonezji, stwierdzając, że ,autorom zależało na takiej selekcji państw, która umożliwiłaby jak najbardziej reprezentatywny, a przy tym też wyrazisty opis działań 
podejmowanych w obszarze ochrony środowiska naturalnego [...]" (s. 10). Jako że nie ograniczyli się oni do konkretnego regionu Azji, a ich celem było zaprezentowanie wszystkich państw kontynentu, może dziwić fakt braku reprezentanta republik poradzieckich oraz państw arabskich. Historia, a także kultura tych państw znacząco różni się od tych, które się rozwijały w Azji Południowej bądź na Dalekim Wschodzie. Jest to jednak jedyny zarzut wobec tej pracy - poza tym należy uznać, że jest ona doskonałym przyczynkiem do dalszych prac w tej dziedzinie.

Druga praca, w której dostrzegłem pewne istotne problemy, to Zastosowanie odnawialnych źródet energii w Japonii. Główny zarzut dotyczy w tym przypadku często emocjonalnego tonu wypowiedzi, który osłabia wyrazistość przekazu z powodu opowiedzenia się autora po jednej ze stron. Autor w pewnym momencie stwierdza: „Pomimo nielicznych grup sprzeciwiających się [...] opinia publiczna albo nie dała po sobie poznać, że przejmuje się problemami w elektrowniach, albo jej sprzeciw był skutecznie zagłuszany przez usłużne media masowego przekazu" (s. 39). Niestety nie podaje żadnych argumentów, że taka postawa jest nadal utrzymywana (przykłady, które omawiał wcześniej, dotyczyły wydarzeń historycznych i nie należy wyciągać z nich zbyt daleko idących wniosków). Gdyby ten zarzut wysunąc tylko w stosunku do operatora elektrowni, firmy TEPCO (Tokyo Electric Power Company), dość łatwo dałoby się wykazać, że próbuje ona ukrywać informacje o problemach z reaktorem w Fukushimie ${ }^{2}$. Z drugiej strony media od wydarzeń z roku 2011 informują o protestach ludności przeciw ponownemu otwieraniu elektrowni jądrowych, należy więc się zastanowić, czy opinia o zagłuszaniu przez media sprzeciwu jest słuszna ${ }^{3}$.

Autor mógłby się także zastanowić, czy do analizy wydarzeń w Fukushimie w 2011 r. nie można by zastosować teorii chaosu, a nie tylko bezpośrednio wyprowadzać ją z poprzednich awarii oraz zaniedbań w konserwacji urządzeń. Teoria ta zakłada, że determinizm oraz przewidywalność są prawdziwe tylko dla wąskiej grupy procesów, zatem normą są układy niestabilne ${ }^{4}$. Należałoby więc rozpatrzyć, czy nawet gdyby nie doszło do wcześniejszych zaniedbań i gdyby nie zignorowano potencjalnych niebezpieczeństw, to czy efekt końcowy nie byłby dokładnie taki

${ }^{2}$ Do takich samych wniosków doszedł m.in. Mirosław Dworniczak, Fukushima: Katastrofa, która wciąż trwa, „Gazeta Wyborcza”, 23 września 2014, http://wyborcza.pl/1,75400,16688687,Fukushima_Katastrofa_ktora_wciaz_trwa.html. Przykładem takiego postępowania może być także przeciek radioaktywnej wody z reaktora do oceanu: Martin Fackler, Japan: Leak Is Disclosed at Nuclear Plant, „The New York Times”, 24 lutego 2015, http://www.nytimes.com/2015/02/25/world/ asia/japan-leak-is-disclosed-at-nuclear-plant.html? r $=0$.

${ }_{3}$ Nakashima Takeshi, Nearly 2,000 Protest Restart of 2nd Nuclear Reactor in Kyushu, http:// ajw.asahi.com/article/behind_news/social_affairs/AJ201510130025, „The Asahi Shimbun”, 13 października 2015.

${ }^{4}$ Michał Tempczyk, Teoria chaosu a filozofia, Wydawnictwo CiS, Warszawa 1998, s. 27. 
sam. Bo przy najlepiej działającym systemie oraz dopracowanych procedurach nawet najmniejszy błąd mógłby doprowadzić do tego samego (tzw. efekt motyla ${ }^{5}$ ).

Mimo tych niewielkich wad książkę należy uznać za wyjątkowo wartościową na naszym rynku. Nowych pozycji dotyczących problematyki polityki i bezpieczeństwa energetycznego czy ochrony środowiska nadal jest zbyt mało. Autorzy w swoich pracach przedstawili, w jaki sposób z zagrożeniami podobnymi do tych występujących w Polsce radzą sobie inne państwa mniej lub bardziej rozwinięte. Są to również cenne informacje dla naukowców, nie tylko tych zajmujących się krajami azjatyckimi, ale także pozostałymi regionami świata. Zmiany klimatyczne mają charakter globalny i bez zrozumienia uwarunkowań poszczególnych państw nie da się opisać skutków działań podjętych przez kraje afrykańskie, europejskie czy amerykańskie.

5 Ibidem, s. 320 . 